\title{
Iodinated Compounds and Thyroxine Binding to Albumin in Human Breast Milk
}

\author{
NICOLE ETLING AND FRANÇOISE GEHIN-FOUQUE \\ U.30 INSERM, Hôpital des Enfants-Malades, Paris, France
}

\begin{abstract}
Summary
Mature human milk samples from young healthy women on an equilibrated diet contained a mean of $81 \mathrm{ng} / \mathrm{ml}$ total iodine. Iodide represented a mean of $77 \%$ of the total iodine. Of the 22 $\mathrm{ng} / \mathrm{ml}$ organic iodine, there was about $1 \mathrm{ng}$ thyroxine and triiodothyronine and, after pepsin hydrolysis, up to $40 \%$ of organic iodine in monoiodotyrosine form. By electrophoresis, after incubation with radioactive thyroid hormone, we found an absence of binding on thyroxine-binding globulin, but thyroxine and triiodothyronine were bound to albumin with a maximal capacity $\mathbf{5 0}$ times higher than in human serum. All these differences did not favor transport of iodinated compounds from maternal serum to milk. In conclusion, milk iodide was taken up by newborn thyroid to make thyroid hormones.
\end{abstract}

\section{Abbreviations}

$T_{4}$, thyroxine

$\Upsilon_{3}$, triiodothyronine

For the past 10 years, thyroid congenital screening has brought a new approach to the neonatal thyroid function, and thyroxine appeared as the most important feature. These considerations have been certainly related to the interest recently developed by breast milk studies. Sack et al. (19) had found a significant amount of thyroxine in human milk. These last 2 years, using two different sensitive methods, Mallol et al. (10) and Moller et al. (13) found that the thyroxine supplied by breast milk was inadequate for normal neonatal development.

Recently, we have noticed a very low content of thyroid hormones in human breast milk and determined its total iodine level (4). This study presents the chemical form of the iodine and the proteins contained in the human milk with the aim of comparing milk to serum.

\section{MATERIALS AND METHODS}

Pooled and individual mature breast milks were obtained from the Lactarium of the Institut de Puériculture of Paris for the neonates in the Hôpital des Enfants-Malades. The mothers were young, healthy, living in and around the city, and had an equilibrated diet. Some samples of commercial cow milks were used for comparison.

Fresh milk samples were used immediately or kept frozen at $-18^{\circ} \mathrm{C}$. For total iodine determination, the catalytic effect of iodine on the reduction of ceric ions by arsenious acid is used in a Technicon Autoanalyzer. The automatic micromethod was

Received July 21, 1983; accepted January 2, 1984.

Send reprint requests to N. Etling, U.30 INSERM, Hôpital des Enfants-Malades. 149. rue de Sèvres, 75743 Paris Cedex 15. France.

This research was supported by Centre National de la Recherche Scientifique and Institut National de la Santé et de la Recherche Médicale, Paris. applicable in the range of 0.5 to $6 \mathrm{ng} / 0.1-\mathrm{ml}$ sample. Milk was free of substance interfering with the reaction; the recovery of a stable amount of iodine added to the milk was complete. Iodide was determined either after 24-h dialysis against water and/or after shaking with an anion exchange resin (Bio-Rad AG 1-X2 type). Radioimmunoassays used were: $T_{4}(6), T_{3}(18)$, both with curve sensitivity of 20 to $600 \mathrm{pg} /$ assay, and thyroxine-binding globulin with a commercial kit (Behringwerke, Marburg, Germany). Radioactive $T_{4}$ and $T_{3}$ used for radioimmunoassays and for the different incubations had high specific activity $(>1200$ $\mu \mathrm{Ci} / \mu \mathrm{g}$, Amersham, UK). Peroxidase was determined according to Fragu and Nataf (5). Protein determinations were performed after trichloracetic acid precipitation, albumin after ammonium sulfate separation by the method of Lowry et al. (9), and different hydrolysis with protease, trypsin, and pepsin (Sigma Chemical Co, St Louis, MO). Polyacrylamide gel electrophoresis (1) was used for detection of proteins after staining with Amido Schwarz (Merck). Paper electrophoresis was performed (15) to determine the maximal binding capacity of albumin for $T_{4}$ and $T_{3}$; fresh milk was incubated for $4 \mathrm{~h}$ at $37^{\circ} \mathrm{C}$ in the presence of radioactive $\mathrm{T}_{4}$ or $\mathrm{T}_{3}$ enriched with 0.5 to $300 \mu \mathrm{g} / \mathrm{ml}$ of stable hormone (Henning, Berlin, Germany) dissolved in $0.1 \mathrm{M}$ Tris buffer, $\mathrm{pH}$ 8.35. Paper electrophoresis was then carried out in $0.1 \mathrm{M}$ ammonium carbonate buffer for $16 \mathrm{~h}$ at $120 \mathrm{~V}$. The $\mathrm{pH}$ was adjusted by bubbling $5 \% \mathrm{O}_{2}$ and $95 \% \mathrm{CO}_{2}$. This buffer allowed a good separation of albumin from other serum proteins binding $T_{4}$. Iodotyrosine determinations were performed with paper chromatography on hydrolyzed milk (details in Ref. 3). Chromatograms were developed in acetic acid/butanol/water $(5: 78: 17$ by vol) and the iodine content of $1 \times 3 \mathrm{~cm}$ paper strips was measured. Special extractions and incubations are described in "Results."

Means \pm SEM were calculated only for more than 10 different milk samples.

\section{RESULTS}

Total Iodine Contents. The mean of total iodine content of 68 human breast milk samples was $81.6 \pm 5.0 \mathrm{ng} / \mathrm{ml}$ (range, 17 to $205 \mathrm{ng} / \mathrm{ml})$ (Table 1). Total iodine in the lipid fraction $(n=10)$ after centrifugation for $15 \mathrm{~min}$ at $2500 \times g$ was $5.9 \pm 1.7 \%$ of total iodine (range, 0 to $13 \%$ ). For comparison, the cow milk samples $(n=11)$ contained $152.1 \pm 12.3 \mathrm{ng} / \mathrm{ml}$ total iodine (range, 99 to $201 \mathrm{ng} / \mathrm{ml}$ ).

Iodide. In human milk, the mean iodide percentage of total iodine obtained after resin adsorption was $(n=48) 75.4 \pm 2.0$ (range, 45.6 to 93.9 ) and after dialysis $(n=35) 79.3 \pm 1.9$ (range, 50.8 to 96$)$. Iodide in cow milk $(n=11)$ was $90.9 \pm 0.9 \%$ of total iodine by resin (range, 88.2 to 95.8 ) and $90.8 \pm 1.6$ by dialysis technique (range, 76.0 to 94.9 ).

Organic iodine content. The difference between total iodine content and iodide content was calculated and was the mean of results from resin and dialysis techniques. The mean for human 
Table 1. Comparison of the amount of total iodine, iodide, and iodo compounds in human breast milk and commercial cow's milk

\begin{tabular}{lcccc}
\hline & Human milk & $(n)$ & Cow's milk & $(n)$ \\
\hline Total iodine $(\mathrm{ng} / \mathrm{ml})$ & $81.6 \pm 5.0$ & $(68)$ & $152.1 \pm 12.3$ & $(11)$ \\
Iodide & & & & \\
$\quad$ Resin & $75.4 \pm 2.0$ & $(48)$ & $90.9 \pm 0.9$ & $(11)$ \\
Dialysis $(\%$ total iodine) & $79.3 \pm 1.9$ & $(35)$ & $90.8 \pm 1.6$ & $(11)$ \\
Organic iodine $(\mathrm{ng} / \mathrm{ml})$ & $22.2 \pm 2.5$ & & $14.4 \pm 2.1$ &. \\
Thyroxine $(\mathrm{ng} / \mathrm{ml})$ & $0.57 \pm 0.08$ & $(12)$ & Undetectable & \\
Triiodothyronine $(\mathrm{ng} / \mathrm{ml})$ & $0.34 \pm 0.04$ & $(25)$ & $0.76 \pm 0.03$ & $(10)$ \\
Monoiodotyrosine $(\mathrm{ng} / \mathrm{ml})$ & $6-20$ & $(7)$ & ND* & \\
\hline
\end{tabular}

* ND not determined.

breast milk was $22.2 \pm 2.5 \mathrm{ng} / \mathrm{ml}$ with a range of 2.2 to $59.5 \mathrm{ng} /$ $\mathrm{ml}$. The mean organic iodine in cow milk was $14.4 \pm 2.1 \mathrm{ng} / \mathrm{ml}$.

Organic iodine composition. Thyroxine of human milk samples was measured with a very sensitive method directly and after ethanol extraction ( 2 volumes) and after delipidation. The mean $(n=12)$ was $0.57 \pm 0.08 \mathrm{ng} / \mathrm{ml}$ (range, 0.28 to $1.60 \mathrm{ng} / \mathrm{ml}$ ). There was no $\mathrm{T}_{4}$ detected in cow milk. The recovery of radioactive $\mathrm{T}_{4}$ from human milk incubated for $5 \mathrm{~h}$ at $37^{\circ} \mathrm{C}$ and centrifuged $15 \mathrm{~min}$ was $15.9 \pm 1.4 \%$ of total activity (range, 8.2 to 23.4) in the lipid fraction.

Triiodothyronine in human milks was determined either directly or after ethanol extraction. Various amounts of $\mathrm{T}_{3}(45,68$, 91 , and $136 \mathrm{pg}$ ) were added to different milk samples; the recovery after direct determination was $93.8 \%(n=7)$ and $90.9 \%$ $(n=6)$ after ethanol extraction. Curves with $20,40,60,80,100$, and $120 \mu \mathrm{l}$ of nonextracted milk were parallel to standard curve as were serial dilutions of the extracted samples from 30 to 150 $\mu \mathrm{l}$. The mean $\mathrm{T}_{3}$ obtained $(n=25)$ was $0.34 \pm 0.04 \mathrm{ng} / \mathrm{ml}$ (range, 0.19 to $0.82 \mathrm{ng} / \mathrm{ml}$ ).

The amount of $\mathrm{T}_{3}$ in cow milk $(n=10)$ was $0.76 \pm 0.03 \mathrm{ng} /$ $\mathrm{ml}$ (range, 0.63 to $0.90 \mathrm{ng} / \mathrm{ml}$ ). $20.6 \pm 2.1 \%$ of the total radioactive $\mathrm{T}_{3}$ incubated with human milk was recovered in the lipid phase (range, 14.6 to $33.9 \%$ ).

The mean amount of total $\mathrm{T}_{3}$ and $\mathrm{T}_{4}$ in human milk was about $1 \mathrm{ng} / \mathrm{ml}$ of a total of $22 \mathrm{ng} / \mathrm{ml}$ of organic iodine. $T_{3}$ and $\mathrm{T}_{4}$ were determined after hydrolysis. Pepsin and trypsin were ineffective. After protease hydrolysis, $\mathrm{T}_{4}$ contents were the same as prior to this last step. The amount of $T_{3}$ after protease hydrolysis was irregular, due to analytical artifacts.

In order to evaluate stable iodotyrosine levels, we used paper chromatography. High organic iodine $(40-50 \mathrm{ng} / \mathrm{ml})$ in human milk was not able to migrate while iodine stayed at the origin. After pepsin hydrolysis (protease and trypsin were ineffective), ethanol extraction, chromatography, and stable iodine determination, iodo compounds were recovered at the $R_{F}$ of monoiodotyrosine standard. Mean iodine from monoiodotyrosine was $2.9 \mathrm{ng}(n=7)$ corresponding to 6 to $20 \mathrm{ng} / \mathrm{ml}$ milk.

Proteins: Enzyme. In cow's milk, either pasteurized or sterilized, the proteins were spoiled and could not be used for comparison.

Amounts. Mean of total proteins in human milk samples $(n=$ 16) was $10.1 \pm 0.8 \mathrm{mg} / \mathrm{ml}$ (range, 6.8 to $19.2 \mathrm{mg} / \mathrm{ml}$ ). By ammonium sulfate precipitation, the mean albumin $(n=11)$ was $5.8 \mathrm{mg} / \mathrm{ml}$ (range, 2.5 to $11.6 \mathrm{mg} / \mathrm{ml}$ ) or $54.7 \%$ of total proteins. Thyroxine-binding globulin was too low to be measured, less than $0.2 \mathrm{mg} / \mathrm{liter}$. The methods used to detect peroxidase in thyroid tissue showed no enzyme in human milk.

Binding. The mobility of milk proteins was determined after polyacrylamide gel electrophoresis. There was a large band corresponding to albumin, and sometimes another smaller band corresponding to the albumin dimer. If about $0.1 \mu \mathrm{Ci}$ radioactive $\mathrm{T}_{4}$ was incubated for $2 \mathrm{~h}$ with these milk samples, $90 \%$ of the radioactive $T_{4}$ was bound to albumin and $10 \%$ to albumin dimer.

The maximum binding capacity of albumin was determined after incubations of human fresh milk samples with radioactive $T_{4}$ or $T_{3}$. On each electrophoresis paper sheet, there was a human serum sample as control and five samples of $50 \mu \mathrm{l} \mathrm{milk}$ incubated previously (see "Materials and Methods") with increasing amount of stable $\mathrm{T}_{4}(0.2$ to $1,0.5$ to $10,10,33,100$, and $166 \mu \mathrm{g}$ and even $50,100,200$, and $300 \mu \mathrm{g} / \mathrm{ml})$ and of stable $\mathrm{T}_{3}(0.05$ to 1 and 1 to $50 \mu \mathrm{g}$, and 66,200 , and $300 \mu \mathrm{g} / \mathrm{ml})$. The measured radioactivity on albumin spots varied from 76 to $91 \%$ of total radioactivity. The maximal binding of $T_{4}$ to serum standard is 4 $\mu \mathrm{g} / \mathrm{ml}$ on albumin. With milk, the maximal binding of $T_{4}$ and $\mathrm{T}_{3}$ was about 50 times higher than with serum and the binding was as high with $T_{3}$ as with $T_{4}$. The uptake of radioactive $T_{4}$, after 2 -h incubation with human milk was temperature $(4,20$, or $37^{\circ} \mathrm{C}$ ) independent.

\section{DISCUSSION}

$\mathrm{T}_{4}$ has been found in human milk in sufficient amounts to attenuate congenital hypothyroidism $(2,19)$. However, the methods used were inadequate. Some authors using either sophisticated analytical methods $(10,13)$ or different sorts of kits (11) recently showed that the $T_{4}$ content in human milk was very low. We have also used a radioimmunoassay which is 40 times more sensitive than the usual commercial kits and our results showed that breast milk contained less than $1 \mathrm{ng} \mathrm{T} / 4 / \mathrm{ml}$. We also showed that cow's milk samples, and consequently formula milk, were free of $\mathrm{T}_{4}$. Few authors, besides Varma et al. (23), Sato and Suzuki (20), and Mizuta et al. (11) have determined $\mathrm{T}_{3}$. In human milk, we found about $0.3 \mathrm{ng} \mathrm{T}_{3} / \mathrm{ml}$, close to the above values and nearly double in cow's milk (Table 1). Human milk was also different from cow's milk because of the absence of peroxidase of the thyroid tissue type, but there is probably one derived from leukocytes (12) and by the very small amount of casein.

$\mathrm{T}_{4}$ could be derived from circulating maternal plasma and we have determined in the milk its characteristics and compared them to serum. The first information was the total iodine content. In studies concerning the mineral content of human milk (22), iodine was omitted. The means found in a Paris neighborhood population were $81 \mathrm{ng} / \mathrm{ml}$, a value close to the total iodine serum content in euthyroid subjects. Iodine was mostly in an iodide form $(77 \%)$ in human milk and, in serum free of interfering drugs, iodide is only about $1 \%$ of total iodine. Milk contained hormones corresponding to $1 / 80$ of total iodine while serum had mostly thyroid hormones. Several groups working on animal milks $(16,10,24)$, using radioactive iodine, have shown a different distribution between iodide, total iodine, and hormone, depending on the species. They usually found that the most abundant organic iodine compound was monoiodotyrosine. In human milk, organic iodine could migrate on paper chromatography after pepsin hydrolysis and in organic iodine rich milks about $40 \%$ was in monoiodotyrosine form. Its serum origin was however doubtful. Protease hydrolysis did not seem to increase $\mathrm{T}_{4}$ content in human milk while it interfered with the $\mathrm{T}_{3}$ radioimmunoassay, though larger amounts have been found (14). Some authors $(2,21)$ had noticed a larger uptake on the lipid milk phase. We have shown that the distribution of $\mathrm{T}_{4}$ was more dependent on the volume of the lipid fraction and our mean value was not very different from the $90 \%$ recovery in the aqueous phase found by Moller et al. (13). 
The second series of experiments concerned the eventual binding of the hormones by proteins. $T_{4}$ was not bound to a specific protein as in serum. This is different from the binding of milk cortisol (17). The amount of total proteins in mature milks was about $1 / 6$ of the serum protein contents and these results agreed with previous report (7). The binding of thyroxine to milk proteins was different from serum binding, particularly because of the absence of a thyroxine-binding globulin. $T_{4}$ and $T_{3}$ might be bound to albumin, both with high capacity, and this phenomenon was temperature independent. By chemical methods, the albumin origin could not be determined. The very low amount of hormones could be transported from maternal serum. Mizuta et al. (11) assume that transfer from serum to milk is a simple diffusion, but they believe that the real mechanism is not elucidated. The monoiodotyrosine origin has to be different and one hypothesis is that it is formed by the lactating breast.

In conclusion, it would seem that the hormones in human milk are in a too low concentration to supply neonates with a normal thyroid function if the gland is deficient. The neonates are able to make their thyroid hormones from the iodine contained in the milk exactly as does the adult with his various intake.

Acknowledgment. The authors express their thanks to Michele Harter for preparation of the manuscript.

\section{REFERENCES}

1. Barka T 1961 Studies of acid phosphatase. I. Electrophoretic separation of acid phosphatases of rat liver on polyacrylamide gels. J Histochem Cytochem $9: 542$

2. Bode HH, Vanjonack WJ, Crawford JD 1978 Mitigation of cretinism by breast feeding. Pediatrics 62:13

3. Etling N 1977 Concentration of thyroglobulin, iodine content of thyroglobulin and of iodoamino acids in human neonates thyroid glands. Acta Paediatr Scand 66:97

4. Etling N. Padovani E. Gehin-Fouque F. Tato L 1982 Composés iodés de laits maternels et maternisés. Ann Endocrinol 43:135 (abstr)

5. Fragu P, Nataf B 1974 Activité péroxydasique de goitres sporadiques humains et de goîtres provoqués chez les rats. CR Acad Sci 279:1269

6. Institut Pasteur Production 1976 Unité de Radioimmunologie Analytique (fiche 79.680). Institut Pasteur, Paris

7. Kleinman R, Jacobson L. Hormann E. Walker WA 1980 Protein values of milk samples from mothers without biologic pregnancies. J Pediatr 97:612

8. Letarte J, Guyda H, Dussault JH, Glorieux J 1980 Lack of protective effect of breast-feeding in congenital hypothyroidism: report of 12 cases. Pediatrics 60:703

9. Lowry OH, Rosebrough NJ, Farr AL, Randall RJ 1951 Protein measurement with the Folin phenol reagent. J Biol Chem 193:265

10. Mallol J, Obregon MJ, Morreale de Escobar G 1982 Analytical artifacts in radioimmunoassay of 1-thyroxin in human milk. Clin Chem 28:1277

11. Mizuta $H$. Amino N. Ichiara $K$, Harada T, Nose $O$, Tanizawa $O$, Miyai $K$ 1983 Thyroid hormones in human milk and their influence on thyroid function of breast-fed babies. Pediatr Res 17:468

12. Moldoveanu Z Tenovuo J, Mestecky J, Pruitt KM 1982 Human milk peroxidase is derived from milk leukocytes. Biochim Biophys Acta 718:103

13. Moller B, Björkhem I, Falk O, Lantto O, and Larsson A 1983 Identification of thyroxine in human breast milk by gas chromatography-mass spectrometry. J Clin Endocrinol Metab 56:30

14. Oberkotter LV, Tenore A 1983 Separation and radioimmunoassay of $T_{3}$ and $T_{4}$ in human breast milk. Hormone Res 17:11

15. Oppenheimer JH, Werner SC 1966 Effect of prednisone on thyroxine binding proteins. J Clin Endocrinol Metab 26:715

16. Potter GD. Tong W. Chaikoff IL 1959 The metabolism of ${ }^{131}$ I-labeled iodine, thyroxine, and triiodothyronine in the mammary gland of the lactating rat. J Biol Chem 234:350

17. Rosner W, Beers PC, Awan T, Khan MS 1976 Identification of corticosteroidbinding globulin in human milk: measurement with a filter disk assay. $\mathrm{J}$ Clin Endocrinol Metab 42:1064

18. Roux D. Peyrin JO, Chambosse A, Bornet H 1975 Dosages immunologiques sans extraction de la L-triiodothyronine dans le sérum humain. CR Soc Biol 169:354

19. Sack J. Amado O, Lunenfeld B 1977 Thyroxine concentration in human milk. J Clin Endocrinol Metab 45:174

20. Sato T. Suzuki Y 1979 Presence of triiodothyronine, no detectable thyroxine and reverse triiodothyronine in human milk. Endocrinol Jpn 26:507

21. Strbak V. Macho L, Knopp J. Struharova L 1974 Thyroxine content in mother milk and regulation of thyroid function of suckling rats. Endocrinol Exp 8:59

22. Vaughan LA, Weber CW, Kemberling SR 1979 Longitudinal changes in the mineral content of human milk. Am J Clin Nutr 32:2301

23. Varma SK, Collins M, Row A, Haller WS, Varma K 1978 Thyroxine, triiodothyronine and reverse triiodothyronine concentrations in human milk. J Pediatr 93:803

24. Vigouroux E, Rostaqui N, Fenerole JH 1980 Estimation of hormonal and nonhormonal iodine uptake from maternal milk in suckling rats. Acta Endocrinol 93:332 